\title{
Effect of Growth Hormone on Oral Glucose Tolerance and Circulating Metabolic Fuels in Man
}

\author{
R. S. Sherwin, G. A. Schulman, R. Hendler, M. Walesky, A. Belous and W. Tamborlane ${ }^{1}$ \\ Departments of Internal Medicine and ${ }^{1}$ Pediatrics, Yale University School of Medicine, New Haven, Connecticut, USA
}

\begin{abstract}
Summary. We infused growth hormone into normal subjects in doses that raised circulating hormone to levels $(30-35 \mathrm{ng} /$ $\mathrm{ml}$ ) similar to those seen during stress. Growth hormone excess failed to alter fasting glucose and somatomedin concentrations. However, non-esterified fatty acids and ketones increased by $50 \%(p<0.05)$ and $120 \%(p<0.01)$, respectively, despite $35 \%$ higher plasma insulin concentrations. When oral glucose was ingested $5 \mathrm{~h}$ after initiating the growth hormone infusion, plasma glucose rose by $2-2.5 \mathrm{mmol} / 1$ above control (saline infusion) values and the area under the glucose curve increased twofold $(p<0.005)$. This occurred in the face of twofold higher insulin levels and normal suppression of
\end{abstract}

glucagon. Growth hormone also did not affect the hyperglycaemic response to a combined infusion of cortisol, glucagon and adrenaline, but accentuated the rise in non-esterified fatty acids, ketones, and insulin caused by these hormones. Our data suggest that growth hormone excess rapidly produces insulin antagonistic effects that may contribute to stress-induced glucose intolerance and lipolysis, even though fasting glucose levels remain unchanged.

Key words: Growth hormone, insulin, glucose tolerance, lipolysis, ketosis, amino acids, insulin resistance, stress.
It is well recognized that chronic growth hormone excess, as in acromegaly, increases the risk of diabetes mellitus [1] and causes glucose intolerance and hyperinsulinaemia in patients with normal fasting glucose levels [2-4]. A similar impairment of glucose disposal and accelerated lipolysis has been reported after administration of large pharmacological doses of growth hormone to normal subjects [5-9]. However, these insulin antagonistic effects of growth hormone are characteristically preceded by a rapid-onset insulin-like action on glucose and lipid metabolism [10-14].

Much less is known about the metabolic effects of acute increments of growth hormone to within the range commonly observed during severe illness [15-18]. Recently, Metcalfe et al. [19] reported that such growth hormone elevations do not alter fasting glucose or nonesterified fatty acid (NEFA) levels in normal subjects, unless insulin secretion is suppressed by somatostatin. They concluded that the hyperglycaemic and lipolytic actions of growth hormone in the basal state are normally prevented by mild compensatory hyperinsulinaemia [19]. With respect to glucose tolerance, previous studies have focused on the intravenous route of glucose delivery. It has been shown that glucose tolerance is impaired in normal subjects within $1-5 \mathrm{~h}$ of raising growth hormone to pathophysiological concentrations $[20,21]$. In those studies, however, growth hormone either caused a decrease (rather than increase) in glucosestimulated insulin release [20] or endogenous insulin secretion was suppressed by somatostatin [21]. Consequently it is possible that insulin lack contributed to the impairment of glucose disposal and that this effect would be less pronounced during oral glucose administration, a more intense stimulus of insulin secretion [22].

In this study we evaluated the influence of 'stresslike' increments of growth hormone on circulating fuels (glucose, NEFA, ketone bodies and amino acids) in the basal state and on the disposal of an oral glucose load in normal subjects. In addition, we examined whether growth hormone accentuated the metabolic effects of other counter-regulatory hormones by infusing growth hormone together with cortisol, glucagon and adrenaline. These studies are of particular interest since (a) counter-regulatory hormones (including growth hormone) increase simultaneously during stress [15-18] and (b) earlier studies have shown that counter-regulatory hormones (glucagon, adrenaline, and cortisol) interact synergistically to promote hyperglycaemia in normal subjects $[23,24]$. 


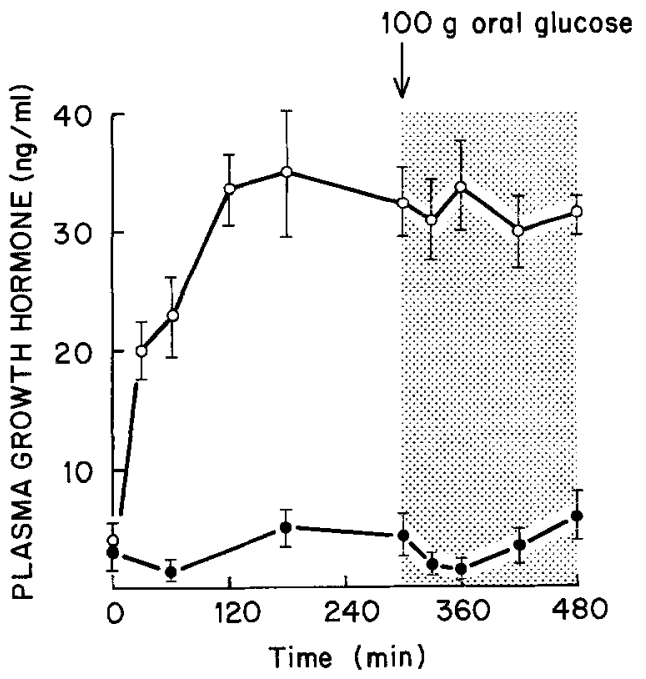

Fig. 1. Plasma growth hormone concentrations during infusion of growth hormone $(\mathrm{O}-\mathrm{O})$ and saline $(-\longrightarrow)$ in normal subjects $(n=8)$. The shaded area denotes the period after glucose ingestion

\section{Subjects and Methods}

\section{Subjects}

Twenty-four healthy volunteers (13 males and 11 females) aged $18-38$ years were studied. All were within $20 \%$ of ideal body weight (based on Metropolitan Life Insurance Tables, 1959). They consumed weight-maintaining diets containing at least $200 \mathrm{~g}$ of carbohydrate and were taking no drugs. None had a family history of diabetes or an elevated fasting plasma glucose concentration $(>5.5 \mathrm{mmol} / \mathrm{l})$. The subjects were informed of the nature, purpose, and possible risks of the study before their written, voluntary consent to participate was obtained. The experimental protocol was approved by the Human Investigations Committee of the Yale University School of Medicine.

\section{Procedures}

All studies were performed in the morning after a $12-16 \mathrm{~h}$ overnight fast. A polyethylene catheter was inserted into an antecubital vein for blood sampling and in the contralateral vein for growth hormone (or saline) administration. Subjects then rested in the recumbent position for at least $30 \mathrm{~min}$ before obtaining baseline blood samples (at $-15 \mathrm{~min}$ and $0 \mathrm{~min}$ ).

Two experimental protocols were used. In the first, human growth hormone $(2 \mathrm{U} / \mathrm{mg}$ ) (obtained from the National Pituitary Agency, Baltimore, Maryland) or saline was infused for $8 \mathrm{~h}$ into eight normal subjects. After $5 \mathrm{~h}, 100 \mathrm{~g}$ of glucose was ingested and the growth hormone or saline $(0.154 \mathrm{~mol} / 1)$ infusion continued for the remaining $3 \mathrm{~h}$ of the study. Each subject was studied on two occasions in random order. Growth hormone was infused at a rate of $3 \mu \mathrm{g} \cdot \mathrm{kg}$ body weight ${ }^{-1} \cdot h^{-1}$. In four of the subjects, a blood sample was obtained before and $300 \mathrm{~min}$ after growth hormone infusion for determination of somatomedin-C concentration.

In the second series of experiments, we infused either cortisol, glucagon, and adrenaline in combination $(n=10)$ or growth hormone together with the triple hormone infusion $(n=6)$. Cortisol was given as a primed continuous infusion for $330 \mathrm{~min}$. The priming dose was given over the initial $150 \mathrm{~min}$ at twice continuous infusion rate $\left(5 \mathrm{mg} \cdot \mathrm{m}^{2}\right.$ body surface area $\left.{ }^{-1} \cdot \mathrm{min}^{-1}\right)$. After the priming dose of cortisol was completed (at $150 \mathrm{~min}$ ), glucagon $\left(3 \mathrm{ng} \cdot \mathrm{kg}\right.$ body weight ${ }^{-1} \cdot \mathrm{min}^{-1}$ ) and adrenaline $\left(1.2 \mathrm{\mu g} \cdot \mathrm{m}^{2}\right.$ body surface area $\left.{ }^{-1} \cdot \mathrm{min}^{-1}\right)$ were added and all three hormones continued for an additional $3 \mathrm{~h}$. Growth hor- mone was infused at a rate of $3 \mu \mathrm{g} \cdot \mathrm{kg}$ body weight ${ }^{-1} \cdot \mathrm{h}^{-1}$ for $330 \mathrm{~min}$ commencing at the start of the cortisol infusion. Data from the triple hormone infusion have been published in part in an earlier report [24].

\section{Analyses}

Plasma glucose concentration was determined by the glucose oxidase method using a Beckman glucose analyzer (Beckman Instruments, Fullerton, California). Plasma levels of insulin [25], glucagon (using Unger antibody $30 \mathrm{~K}$ ) [26], growth hormone [27] and somatomedin-C [28] were quantitated by radioimmunoassay. The sensitivity (detection limit for small concentrations of hormone) and coefficient of variation (determined by replicate analysis of quality control samples over a 1-2 year period) for the insulin, glucagon and growth hormone assays are as follows: (1) insulin $3 \mathrm{mU} / 1$ and $10 \%$; (2) glucagon $20 \mathrm{pg} / \mathrm{ml}$ and $8 \%$; and (3) growth hormone $1 \mathrm{ng} / \mathrm{ml}$ and 16\%. Plasma adrenaline and noradrenaline were determined by a radio-enzymatic technique [29] and plasma cortisol by a fluorometric method [30]. Total blood ketones were quantitated using an enzymatic method [31] and plasma NEFA were measured colorimetrically by the method of Novak [32]. Plasma alanine and branched chain amino acids were assayed by ion-exchange chromatography [26].

Statistical analyses were performed using the Student's t-test. The paired $\mathbf{t}$-test was used when comparing results from the paired growth hormone and saline infusions. All data in the text and figures are presented as the mean \pm SEM.

\section{Results}

\section{Growth Hormone Concentration}

Changes in plasma growth hormone concentrations during exogenous hormone infusion are shown in Figure 1. Plasma growth hormone increased rapidly, reaching a plateau of $30-35 \mathrm{ng} / \mathrm{ml}$ within $2 \mathrm{~h}$. In contrast, growth hormone levels remained $<5 \mathrm{ng} / \mathrm{ml}$ during infusion of saline $(p<0.001$ versus growth hormone infusion). A transient $50 \%$ decline in growth hormone levels was seen after glucose ingestion in saline controls $(p<$ 0.05 ), but not in the growth hormone-infused subjects.

\section{Basal Substrates}

As shown in Table 1, the growth hormone infusion had no significant effect on post-absorptive plasma glucose concentration throughout the $5 \mathrm{~h}$-period before glucose ingestion. Basal insulin concentration tended to rise during growth hormone infusion and fall during saline administration, although these changes were not themselves statistically significant when compared with time 0 values. As a result, at $5 \mathrm{~h}$ plasma insulin was significantly greater after the growth hormone infusion when compared with the saline control study $(p<0.005)$. Basal concentrations of glucagon and catecholamines were comparable in growth hormone and saline infusion studies.

The effect of the growth hormone on basal concentrations of NEFA and ketones is shown in Figure 2. Within $3 \mathrm{~h}$ growth hormone infusion produced a significant elevation in both plasma NEFA and blood ketones compared with the saline control study $(p<0.05)$. Fast- 
Table 1. Effect of growth hormone infusion on plasma glucose, insulin, glucagon, and catecholamine concentrations before glucose ingestion in eight normal subjects

\begin{tabular}{|c|c|c|c|c|c|c|c|}
\hline & Infusion & \multicolumn{6}{|l|}{ Time (min) } \\
\hline $\begin{array}{l}\text { Glucose } \\
(\mathrm{mmol} / 1)\end{array}$ & $\begin{array}{l}\text { Growth hormone } \\
\text { Saline }\end{array}$ & $\begin{array}{l}4.9 \pm 0.1 \\
5.0 \pm 0.1\end{array}$ & $\begin{array}{l}4.9 \pm 0.2 \\
5.1 \pm 0.2\end{array}$ & $\begin{array}{l}4.8 \pm 0.1 \\
4.9 \pm 0.1\end{array}$ & $\begin{array}{l}4.7 \pm 0.1 \\
4.8 \pm 0.1\end{array}$ & $\begin{array}{ll}4.7 \pm & 0.1 \\
4.7 \pm & 0.1\end{array}$ & $\begin{array}{l}4.7 \pm 0.1 \\
4.8 \pm 0.1\end{array}$ \\
\hline $\begin{array}{l}\text { Insulin } \\
(\mathrm{mU} / \mathrm{l})\end{array}$ & $\begin{array}{l}\text { Growth hormone } \\
\text { Saline }\end{array}$ & $\begin{array}{l}14 \pm 1 \\
16 \pm 2\end{array}$ & $\begin{array}{l}15 \pm 1 \\
16 \pm 1\end{array}$ & $\begin{array}{l}13 \pm 1 \\
13 \pm 1\end{array}$ & $\begin{array}{l}14 \pm 1 \\
13 \pm 1\end{array}$ & $\begin{array}{l}17 \pm 1^{\mathrm{a}} \\
13 \pm 1\end{array}$ & $\begin{array}{l}16 \pm 1^{b} \\
12 \pm 1\end{array}$ \\
\hline $\begin{array}{l}\text { Adrenaline } \\
(\mathrm{pg} / \mathrm{ml})\end{array}$ & $\begin{array}{l}\text { Growth hormone } \\
\text { Saline }\end{array}$ & $\begin{array}{l}33 \pm 6 \\
37 \pm 9\end{array}$ & $\begin{array}{l}- \\
-\end{array}$ & - & & $\begin{array}{l}19 \pm 6 \\
17 \pm 4\end{array}$ & $\begin{array}{l}19 \pm 6 \\
23 \pm 4\end{array}$ \\
\hline $\begin{array}{l}\text { Noradrenaline } \\
(\mathrm{pg} / \mathrm{ml})\end{array}$ & $\begin{array}{l}\text { Growth hormone } \\
\text { Saline }\end{array}$ & $\begin{array}{l}215 \pm 15 \\
232 \pm 16\end{array}$ & $\begin{array}{l}- \\
-\end{array}$ & $\begin{array}{l}- \\
-\end{array}$ & & $\begin{array}{l}227 \pm 26 \\
224 \pm 24\end{array}$ & $\begin{array}{l}250 \pm 18 \\
231 \pm 24\end{array}$ \\
\hline
\end{tabular}

Data presented as mean \pm SEM. Control values $(0 \mathrm{~min})$ represent the mean of two observations on each subject preceding growth hormone infusion. ${ }^{\mathrm{a}} p<0.05,{ }^{\mathrm{b}} p<0.005$ refer to significance of difference from saline control study (paired t-test). Only values which differ significantly are indicated

ing NEFA and ketone levels were increased by $50 \%$ $(p<0.05)$ and $120 \%(p<0.01)$, respectively, before glucose ingestion (at $5 \mathrm{~h}$ ). As shown in Table 2, plasma alanine fell from pre-infusion values during growth hormone infusion, but remained unchanged in the saline control study. The decline in plasma alanine exceeded that observed in saline controls within $4 \mathrm{~h}(-70 \pm 12$ versus $-29 \pm 15 \mu \mathrm{mol} / 1 ; \quad p<0.05)$. Branched chain amino-acid concentrations, on the other hand, were not altered by either growth hormone or saline administration. In the four subjects in whom plasma somatomedin- $C$ concentration was measured, there was no significant change during growth hormone infusion $(1.7 \pm 0.4$ basal versus $1.8 \pm 0.5 \mathrm{U} / \mathrm{ml}$ at $5 \mathrm{~h})$.

\section{Effect on Oral Glucose Tolerance}

Figure 3 demonstrates the plasma glucose and insulin responses to the $100 \mathrm{~g}$ oral glucose load. Although growth hormone infusion had no significant effect on basal glucose levels, a marked deterioration in glucose tolerance was observed. Plasma glucose levels were $2.0-2.5 \mathrm{mmol} / \mathrm{l}$ above the corresponding saline control values from $90 \mathrm{~min}$ after oral glucose until the end of the study $(90 \mathrm{~min}: 9.4 \pm 0.6$ versus $7.1 \pm 0.6 \mathrm{mmol} / 1$, $p<0.005 ; 120 \mathrm{~min}: 9.0 \pm 0.7$ versus $6.7 \pm 0.4 \mathrm{mmol} / 1$, $p<0.01$; $180 \mathrm{~min}: 6.9 \pm 0.7$ versus $4.7 \pm 0.3 \mathrm{mmol} / \mathrm{l}$, $p<0.05$ ). In addition, the incremental area under the glucose response curve was increased by $85 \%$ in the growth hormone-infused subjects compared with the saline control group $(0.62 \pm 0.09$ versus $0.33 \pm 0.06$ $\left.\mathrm{mol} \cdot 1^{-1} \cdot \min ^{-1}, p<0.005\right)$.

The impaired glucose tolerance produced by growth hormone occurred in spite of an increase in circulating insulin concentration. Plasma insulin in the growth hormone-infused group was significantly elevated compared with saline control group beyond $60 \mathrm{~min}(p<0.02$ $-p<0.005)$ and the incremental area under the insulin
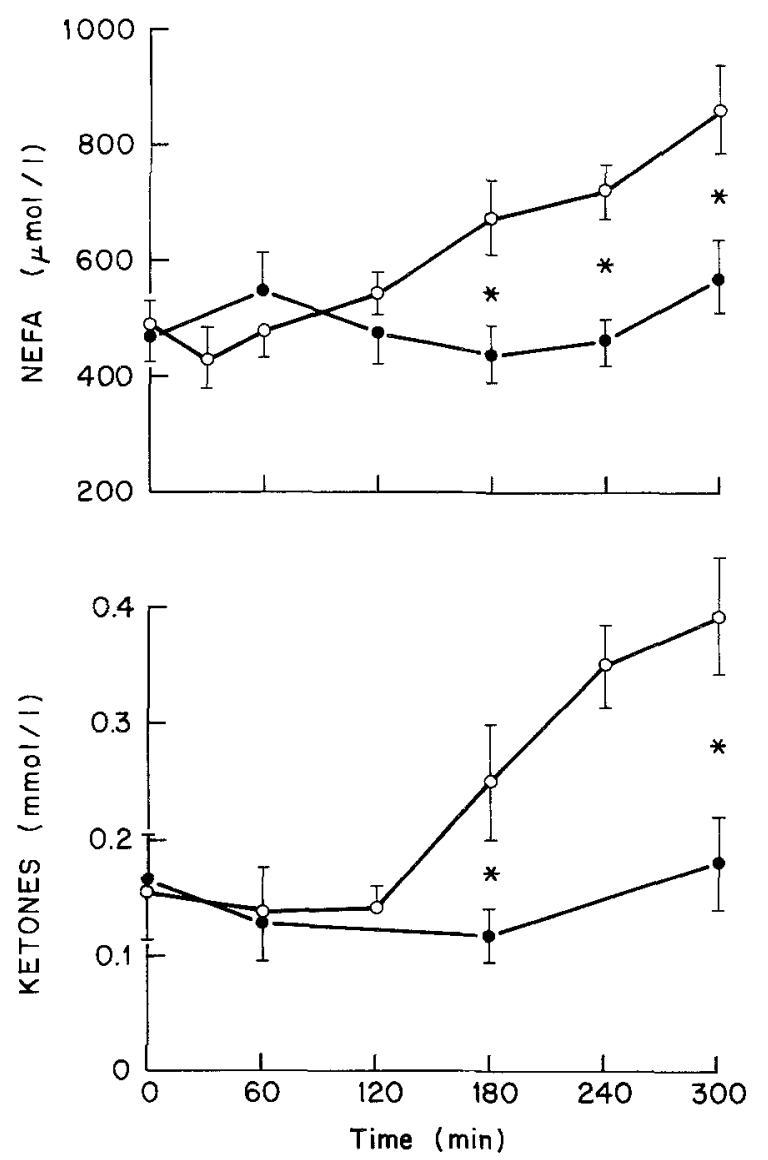

Fig. 2. Effect of growth hormone infusion on plasma non-esterified fatty acids (NEFA) and total blood ketones in the post-absorptive state. * denotes a significant difference $(p<0.05)$ between growth hormone $(\mathrm{O} \longrightarrow \mathrm{O})$ and saline control values $(\longrightarrow)$

response curve was $82 \%$ greater after growth hormone administration $\left(18.4 \pm 3.3\right.$ versus $10.1 \pm 2.3 \mathrm{U} \cdot 1^{-1}$. $\mathrm{min}^{-1}$ in saline control subjects, $p<0.005$ ). There was no significant correlation between the plasma glucose and insulin response after glucose ingestion $(r=-0.2$, 
Table 2. Effect of 5-h infusion of growth hormone on the basal concentrations of plasma amino acids in eight normal subjects

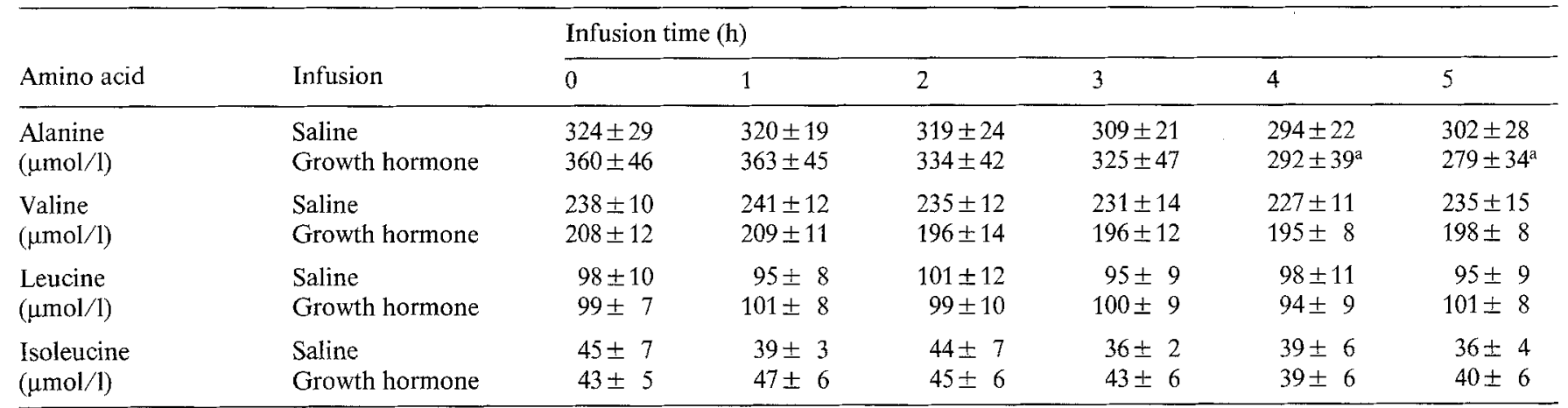

Data presented as mean $\pm S E M$. Control values $(0 \mathrm{~min})$ represent the mean of two observations on each subject preceding growth hormone administration. ${ }^{a}$ indicates $p<0.005$ versus pre-infusion values
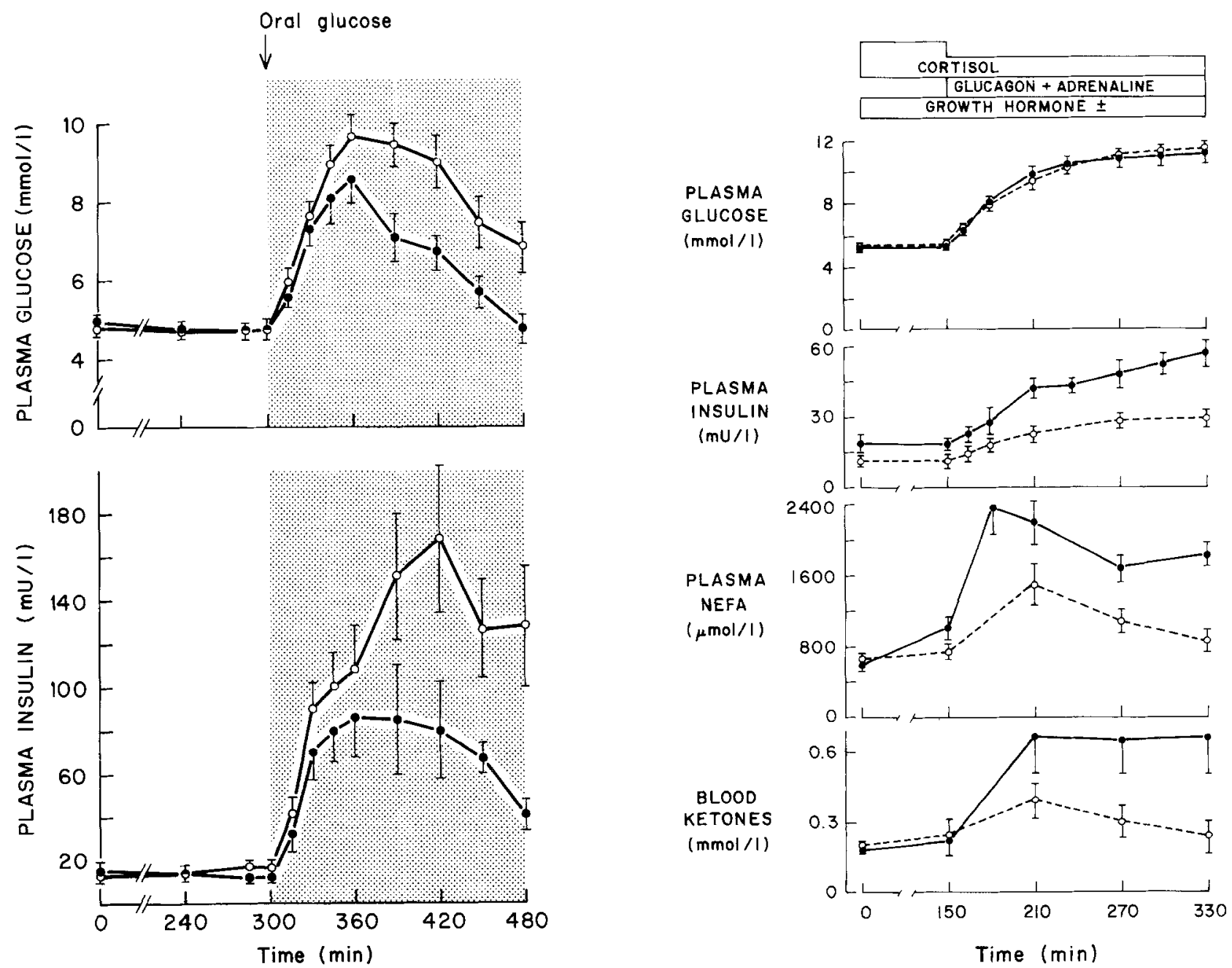

Fig. 3. Effect of growth hormone $(\mathrm{O}-\mathrm{O})$ ) and saline $(-<)$ infusion on the plasma glucose (upper panel) and insulin (lower panel) response to oral glucose ingestion $(100 \mathrm{~g})$ in normal subjects. The shaded area denotes the period after glucose ingestion

$p>0.05$ ) or between the concentration of growth hormone achieved during the infusion and post-prandial glucose levels $(r=-0.07, p>0.05)$. Plasma glucagon fell after glucose ingestion in both the growth hormone

Fig. 4. Changes in plasma glucose, insulin, non-esterified fatty acids (NEFA) and total blood ketones during the combined infusion of growth hormone, cortisol, glucagon and adrenaline $(-1 n=6)$ compared with changes when growth hormone was omitted $(0-\cdots)(n=10)$

(from $135 \pm 11$ to $91 \pm 13 \mathrm{pg} / \mathrm{ml}, p<0.05$ ) and salineinfused subjects (from $125 \pm 20$ to $108 \pm 15 \mathrm{pg} / \mathrm{ml}$, $p<0.05$ ). These differences were not statistically significant between the groups. 


\section{Effect of Growth Hormone on the Response to Other Counter-Regulatory Hormones}

When growth hormone was combined with infusion of cortisol, glucagon, and adrenaline, plasma growth hormone levels rose to $35 \pm 2 \mathrm{ng} / \mathrm{ml}$ (data not shown; NS versus infusion of growth hormone alone). As shown in Figure 4, the addition of growth hormone did not alter the plasma glucose response to the other counter-regulatory hormones. At the completion of the infusions plasma glucose concentration was $11.1 \pm 0.7 \mathrm{mmol} / 1$ when all four hormones were given and $11.5 \pm 0.3$ $\mathrm{mmol} / 1$ when growth hormone was omitted $(p=\mathrm{NS})$. In contrast, both the rise in plasma NEFA and blood ketones were accentuated by growth hormone (Fig. 4). Growth hormone infusion increased plasma NEFA concentration during the cortisol priming period $(1009 \pm 120$ versus $736 \pm 66 \mu \mathrm{mol} / 1$ at $150 \mathrm{~min}, p<0.05)$ and resulted in a twofold greater rise in plasma NEFA when cortisol, glucagon and adrenaline were infused simultaneously $(1820 \pm 240$ versus $859 \pm 131 \mu \mathrm{mol} / 1$ at 330 min, $p<0.001)$. Similarly, blood ketone levels were twofold higher when growth hormone was added to the other counter-regulatory hormones $(p<0.05)$. In the group receiving growth hormone, plasma insulin concentration was slightly increased in the basal state $(19 \pm 4$ versus $11 \pm 1 \mathrm{mU} / 1$ at $0 \mathrm{~min}, p<0.05)$ and rose to levels twofold above those observed during the triple hormone infusion $(58 \pm 6$ versus $29 \pm 4 \mathrm{mU} / 1$ at 330 $\mathrm{min}, p<0.001)$. Plasma cortisol $(35-45 \mu \mathrm{g} / \mathrm{dl})$ and glucagon $(335-375 \mathrm{pg} / \mathrm{ml})$ were not significantly different in the two treatment groups.

\section{Discussion}

We have shown that acute increments of growth hormone do not alter basal glucose levels or the glycaemic response to cortisol, glucagon and adrenaline in normal subjects. Nevertheless, growth hormone impaired oral glucose tolerance and increased the concentrations of NEFA and ketones. These effects do not appear to be mediated by changes in somatomedin-C or glucagon, and occurred in the face of hyperinsulinaemia. The magnitude of the elevations in growth hormone achieved in this study were in the range of those commonly seen in major surgery $[15,16]$, severe trauma [17], or diabetic ketoacidosis [18]. Furthermore, since growth hormone hypersecretion is often sustained in these conditions for many hours or several days [15-18], our findings may be relevant to severe stress in man.

The early insulin-like effect seen with large pharmacological doses of growth hormone [10-14] was not detected in this study. Neither glucose, NEFA, ketones, nor the insulin-sensitive branched chain group of amino acids declined during growth hormone infusion. While these results are in accord with those of Metcalfe et al. [19], Adamson and Cerasi [33] and MacGorman et al.
[21] reported a small $(5 \mathrm{mg} / \mathrm{dl}, 0.28 \mathrm{mmol} / 1)$ reduction in glucose levels 30-120 min after growth hormone administration. The reasons for these modest discrepancies remain uncertain, but it should be noted that the infusion rates used previously $[19,21,33]$ were approximately twofold greater than those used in this study. Acute growth hormone administration also failed to elevate basal glucose levels, even in the setting of combined elevations of multiple counter-regulatory hormones. The latter finding is particularly noteworthy since the hyperglycaemic response to cortisol, glucagon or adrenaline individually is enhanced by elevations in other members of this group of hormones [23, 24]. These data suggest that growth hormone plays an insignificant role in the development of fasting hyperglycaemia during stress in normal man and that the synergistic nature of the interactions among other counter-regulatory hormones with respect to glucose metabolism does not extend to growth hormone during short-term hormone exposure.

In contrast, growth hormone increased circulating NEFA and ketone levels in the fasting state and during combined counter-regulatory hormone infusion. Although earlier studies in man have reported increases in NEFA after large doses of growth hormone [5-7], no such changes have been reported when more physiological doses of the hormone were infused into normal subjects [19]. Our findings, thus, provide evidence that growth hormone hypersecretion contributes to stressinduced lipolysis and that this effect is not due to hypoinsulinaemia. Inasmuch as the ketone elevation accompanying growth hormone infusion closely paralleled the rise in NEFA, it is likely that increased NEFA availability was largely responsible for this phenomenon. Nevertheless our data do not exclude a direct effect of the hormone on the liver. Growth hormone has been shown to increase blood ketones in normal subjects in the absence of a rise in NEFA [19] and to increase ketonaemia in diabetic patients independent of changes in NEFA availability [34].

Despite the lack of effect on basal glucose levels, growth hormone decreased oral glucose tolerance in spite of an exaggerated insulin response. Whether the hyperinsulinaemia is a direct effect of growth hormone, or simply due to the higher glucose levels after growth hormone administration, cannot be resolved by this study. Previous studies, using physiological growth hormone infusions, have also demonstrated an impairment of intravenous glucose tolerance in normal subjects [20, 21]. However, in those studies the glucose intolerance was associated with a diminution in glucose-stimulated insulin levels [20] or occurred during suppression of endogenous insulin with somatostatin [21]. The current data indicate that this action of growth hormone is not dependent on a deficient insulin response (as has also been suggested by Adamson and Efendic [35]). Whether the rapid development of insulin resistance is mediated at the level of the insulin receptor or elsewhere remains 
undetermined. Recent studies are, however, most consistent with a post-receptor mechanism. In the rat, Kahn et al. [36] found only modest changes in insulin binding to hepatocytes after pharmacological growth hormone treatment. Furthermore, Maloff et al. [37] reported that growth hormone has no effect on insulin binding to adipocytes in vitro, despite having direct effects on adipose tissue. It is also possible that the glucose intolerance is, in part, a secondary consequence of the elevated NEFA levels. NEFA has been reported to decrease glucose uptake in vitro [38] and interfere with insulinstimulated glucose metabolism in man [39].

Finally, our data demonstrate that acute elevation of growth hormone does not alter levels of circulating branched chain amino acids and has only a modest lowering effect on alanine levels. Studies using larger doses of growth hormone have shown a more rapid and generalized reduction in plasma amino-acid levels in man [40], which presumably represents a pharmacological action of growth hormone. It remains undetermined whether the slight decline in plasma alanine is caused by growth hormone per se or is secondary to changes in other substrates (e.g. ketones [41]) or hormones. Our failure to observe immediate changes in circulating somatomedin-C (as reported by others with larger doses of growth hormone [42]) make it unlikely that somatomedins mediate this response. Nevertheless, this possibility cannot be entirely excluded, because somatomedin-C may exert its biological effects via local release of the hormone [43].

Acknowledgements. We thank A.Groszman and R.Jacob for their technical assistance and P. Strumpf for secretarial assistance. We are grateful to Dr. R. Donabedian of the Clinical Chemistry Department of his help with the growth hormone measurements and to Dr. L. Underwood of the Department of Pediatrics, University of North Carolina for measuring somatomedin-C levels in our patients and for his valued criticism. This work was supported in part by grants AM20495 and RR125 from the National Institutes of Health. Dr. Sherwin is the recipient of a Research Career Development Award (AM00334) and Dr. Tamborlane is the recipient of a Clinical Investigator Award (AM00621) from the National Institutes of Health.

\section{References}

1. Wright AD, Hill DM, Lowy C, Fraser TR (1970) Mortality in acromegaly. Quart J Med 153:1-16

2. Beck P, Schlach DS, Parker ML, Kipnis DM, Daughaday WH (1966) Correlative studies of growth hormone and insulin plasma concentrations with metabolic abnormalities in acromegaly. J Lab Clin Med 66: 366-379

3. Sonksen PH, Greenwood FC, Ellis JP, Lowy C, Rutherford A, Nabarro JPN (1967) Changes of carbohydrate tolerance in acromegaly with progress of the disease and in response to treatment. J Clin Endocrinol Metab 27:1418-1430

4. Fineberg SE, Merimee TJ, Rabinowitz D, Edgar PJ (1970) Insulin secretion in acromegaly. J Clin Endocrinol Metab 30: 288--292

5. Raben MS, Hollenberg CH (1959) Effect of growth hormone on plasma fatty acids. J Clin Invest 39: 484-489

6. Schlach DS, Kipnis DM (1965) Abnormalities in carbohydrate tolerance associated with elevated plasma non-esterified fatty acids. J Clin Invest 44: 2010-2020
7. Hollobaugh SL, Tzagournis M, Folk RL, Kruger FA, Hamur GJ (1968) The diabetogenic action of human growth hormone glucose-fatty acid interrelationships. Metabolism (Clin Exp) 17: 485-491

8. Daughaday WH, Kipnis DM (1966) The growth-promoting and anti-insulin actions of somatotropin. Rec Prog Horm Res 22: 49-93

9. Rabinowitz D, Klasson GA, Zierler KL (1965) Effect of human growth hormone on muscle and adipose tissue metabolism in the forearm of man. J Clin Invest 44: 51-61

10. Birnbaum RS, Goodman HM (1979) Comparison of several insulin-like effects of growth hormone. Horm Metab Res 11: 136-142

11. Swislocki NI (1968) Effects of nutritional status and the pituitary on the acute plasma free fatty acid and glucose responses of rats to growth hormone administration. Metabolism 17: 174-180

12. Fineberg SE, Merimee TJ (1974) Acute metabolic effects of human growth hormone. Diabetes 23: 499-513

13. Cheng JS, Kalant N (1970) Effects of insulin and growth hormone on flux rates of plasma glucose and plasma free fatty acids in man. $\mathrm{J}$ Clin Endocrinol Metab 31: 647-653

14. Adamson U, Wahren I, Cerasi E (1977) Influence of growth hormone on splanchnic glucose production in man. Acta Endocrinol (Kbh) 86: 803-812

15. Charters AC, Odell WD, Thompson JC (1969) Anterior pituitary function during surgical stress and convalescence. Radioimmunoassay of blood TSH, FSH, LH and growth hormone. J Clin Endocrinol Metab 29: 63-69

16. Wright PD, Johnston IDA (1975) The effect of surgical operation on growth hormone levels in plasma. Surgery 77: 479-486

17. Carey CL, Cloutier T, Lowery BD (1971) Growth hormone and adrenocortical response to shock and trauma in the human. Ann Surg 174: 451-458

18. Cryer PE, Daughaday WH (1970) Diabetic ketosis-serial plasma growth hormone concentrations during therapy. Diabetes 19: $519-523$

19. Metcalfe P, Johnston DG, Nosadini R, Ørksov H, Alberti KGMM (1981) Metabolic effects of acute and prolonged growth hormone excess in normal and insulin-deficient man. Diabetologia 20: $123-128$

20. Adamson V, Cerasi E (1975) Acute effects of exogenous growth hormone in man: time- and dose-bound modification of glucose tolerance and glucose-induced insulin release. Acta Endocrinol 80:247-261

21. MacGorman LR, Rizza RA, Gerich JE (1981) Physiological concentrations of growth hormone exert insulin-like and insulin antagonistic effects on both hepatic and extrahepatic tissues in man. J Clin Endocrinol Metab 53: 556-559

22. DeFronzo RA, Ferrannini AE, Hendler R, Wahren J, Felig P (1978) Influence of hyperinsulinemia, hyperglycemia, and the route of glucose administration on spanchnic glucose exchange. Proc Natl Acad Sci USA 74: 5173-5177

23. Eigler N, Saccà L, Sherwin RS (1979) Synergistic interactions of physiological increments of glucagon, epinephrine, and cortisol in the dog. A model of stress-induced hyperglycemia. J Clin Invest 63: $114-123$

24. Shamoon H, Hendler R, Sherwin RS (1981) Synergistic interactions among anti-insulin hormones in the pathogenesis of stress hyperglycemia in humans. $\mathrm{J}$ Clin Endocrinol Metab 52: 1235-1241

25. Rosselin G, Assan R, Yalow RS, Berson SA (1966) Separation of antibody-bound and unbound peptide hormones labelled with iodine-131 by talcum powder and precipitated silica. Nature (Lond) 212: 355-357

26. Wise J, Hendler R, Felig P (1973) Influence of glucocorticoids on glucagon secretion and plasma amino acid concentrations in man. $\mathrm{J}$ Clin Invest 52: 2774-2782

27. Wright DR, Goodman AD, Trimble KD (1974) Studies on big growth hormone from human plasma and pituitary. J Clin Invest 54: 1064-1073

28. Furlanetto RW, Underwood LE, Van Wyk JJ, D'Erocole AJ (1977) 
Estimation of somatomedin-C levels in normals and patients with pituitary disease by radioimmunoassay. J Clin Invest 60: 648-657

29. Passon PG, Peuler JD (1973) A simplified radiometric assay for plasma norepinephrine and epinephrine. Anal Biochem 51: 618-631

30. DeMoor P, Steeno O, Rankin M, Hendrikx A (1960) Fluorometric determinations of free plasma 11-hydroxycorticoids in man. Acta Endocrinol (Kbh) 33: 297-307

31. Williamson DH, Mellanby J, Krebs HA (1962) Enzymatic determination of $\mathrm{D}(-)$-B-hydroxybutyric acid and acetoacetetic acid in blood. Biochem J 82: 90-96

32. Novak M (1965) Colorimetric ultramicro-method for the determination of free fatty acids. J Lipid Res 6: $431-433$

33. Adamson V, Cerasi E (1975) Acute suppressive effect of human growth hormone on basal insulin secretion in man. Acta Endocrinol 79: 474-482

34. Schade DS, Eaton RP, Peake GT (1978) The regulation of plasma ketone body concentration by counter-regulatory hormones in man. Diabetes 27:916-924

35. Adamson V, Efendic S (1979) Insulin-like and diabetogenic effects of growth hormone in healthy subjects, diabetics, and low insulin responders. J Clin Endocrinol Metab 49: 456-461

36. Kahn CR, Goldfine ID, Neville DM, De Meyts P (1978) Alterations in insulin binding induced by changes in vivo in the levels of glucocorticoids and growth hormone. Endocrinology 103: 1054-1057

37. Maloff B, Levine J, Lockwood D (1980) Direct effects of growth hormone on insulin action in rat adipose tissue maintained in vivo. Endocrinology 107: 538-544
38. Randle JP, Garland PB, Hales CW, Newsholme EA (1963) The glucose fatty acid cycle: its role in insulin sensitivity and the metabolic disturbances of diabetes mellitus. Lancet 1: 785-789

39. Ferrannini E, Barrett E, Bevilacqua S, DeFronzo RA (1981) Effect of free fatty acids on peripheral glucose metabolism in man. Clin Res 29: 405A

40. Jover E, Paradinas C, Velasco R (1977) Metabolic changes induced by human growth hormone. J Med 8: 415-424

41. Sherwin RS, Hendler RG, Felig P (1975) Effect of ketone infusions on amino acid and nitrogen metabolism in man. J Clin Invest 55: $1382-1390$

42. Copeland KC, Underwood LE, Van Wyk JJ (1980) Induction of immunoreactive somatomedin $\mathrm{C}$ in human serum by growth hormone: dose response relationships and effect on chromatographic profiles. J Clin Endocrinol Metab 50: 690-697

43. D'Erocole AJ, Applewhite GT, Underwood LE (1980) Evidence that somatomedin is synthesized by multiple tissues in the fetus. Develop Biol 75: 315-328

Received: 4May 1982

and in revised form: 13 September 1982

Dr. R.S. Sherwin

Yale University School of Medicine

333 Cedar Street, 2076 LMP

New Haven, Connecticut 06510, USA 